Acta vet. scand. $1967,8,234-261$.

From the Department of Pathology, Royal Veterinary College, Stockholm, Sweden.

\title{
HAEMANGIOENDOTHELIOMA IN DOMESTIC ANIMALS
}

\author{
By \\ Tage Waller and Sven Rubarth
}

Comparative pathology has for many years attracted increasing attention and interest within human medicine, since it has contributed to a greater understanding of important medical problems. A study of tumorous growths in animals, for instance, offers valuable contributions to the biology and occurrence of tumours, and in that respect tumours of dogs have yielded much information. We present here our material of haemangioendotheliomas in dogs, by no means an uncommon form of tumour, but one that has been sparsely reported in the literature.

In their descriptions of vascular tumours, the early authors make no sharp distinction between mature and immature growths and, therefore, their data do not allow closer assessment. Feldman (1932), Mulligan (1949), and Moulton (1961) describe haemangioendothelioma on the basis of personal observations, but do not report the number of cases or animal species. They state, however, that the tumour seems to be most common in dogs. Adamek (1934) reports a series of cases from Berlin, collected over the period 1926-1932, and the occurrence of the tumour in various animal species. The largest series are those presented by Mason (1960), consisting of 22 cases of haemangioendothelioma in dogs, and by Brodey (1964), 27 cases of haemangioendothelioma of the spleen in dogs. Most other authors describe the occurrence of the tumour in dogs, reporting one to three cases (Lindsay \& Gilmore 1946, Pounden \& Sprunger 1947, Lieberman 1955, Farrel \& Farrel 1960, and Brandt \& Sofrenovic 1963). A fairly large material obtained from chickens is presented by 
Järplid (1961), The tumour has also been reported to occur in cattle (Renk 1941, Verma 1963), horses (Mench 1963), pigs (Deiner 1923), and monkeys (Jungherr 1963).

\section{MATERIAL AND OBSERVATIONS}

Our material was obtained from autopsies at the Institute of Pathology, Royal Veterinary College, over the years 1940-1965 and comprises 49 dogs, 2 horses, and 2 cows. For the histopathological examination the material was fixed in $10 \%$ formalin and, after embedding in paraffin, stained with haematoxylineosin and van Gieson's stain.

The main interest will here be directed to the dogs, and the other cases will be described briefly.

As a complete case report of each dog would require too much space, and as many of the cases are similar, 3 typical cases will be described in detail.

\section{Case reports}

\section{Case 1}

Poodle, $Q, 10$ years old. The dog was admitted to the Veterinary Institute at Skara, Sweden, for treatment of an abscess in the muscles of the right shoulder. She was found dead in her box April 23, 1962, without having shown any previous signs of disease. According to the owner, she had been in a state of collapse, with dyspnoea, cyanosis, and tachycardia, 10 days before admission.

Autopsy (0. 314/62) on April 27, 1962: The dog was in a medium state of nutrition (weight $13.6 \mathrm{~kg}$ ). On the right shoulder there were two purulent skin sores, beneath which the subcutis was moderately hyperaemic. The pericardium contained half a litre of partly coagulated blood, and caudally on the left chamber of the heart close to the sulcus long. dx., about $3 \mathrm{~cm}$ above the apex of the heart, there was a markedly protuberant dark-red tumour, the size of a walnut, whose surface was covered with blood coagula (Fig. 1). The growth was poorly demarcated from the myocardium and extended for a few $\mathrm{cm}$ into it. The cut surface was relatively homogeneous and darkish red with grey streaks. The heart was also the seat of numerous subepicardial haemorrhages. The spleen was moderately enlarged (weight $0.59 \%$ ) and hyperaemic. The liver showed slight signs of stasis.

Histological examination: The tumour involving the heart showed the picture of a haemangioendothelioma with marked infiltrative growth in the myocardium. The tumour cells were elongated with irregularly shaped, eccentrically placed, large, pale nuclei, some of which had a fairly large, faintly eosinophilic nucleolus. In the parts of the tumour situated beneath the epicardium large cavernous spaces filled 


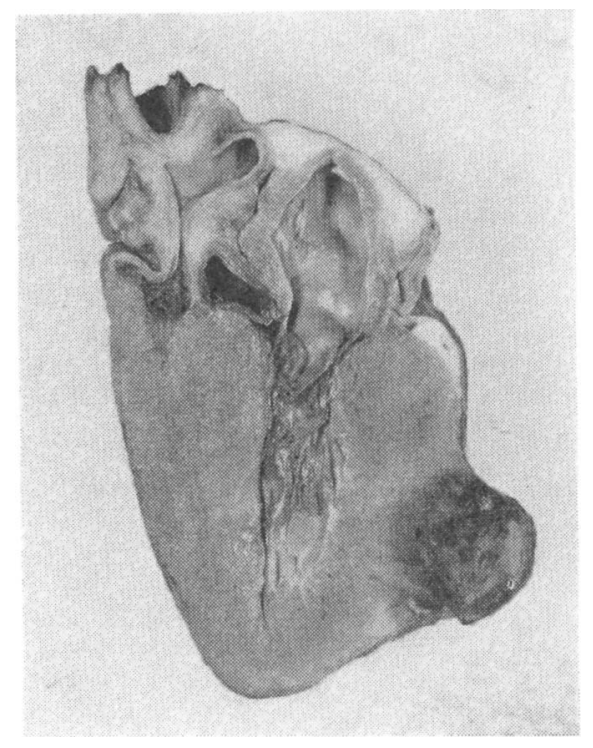

Fig u r e 1. (0.314/62). Infiltrative type of haemangioendothelioma in the left ventricular heart wall. Dog.

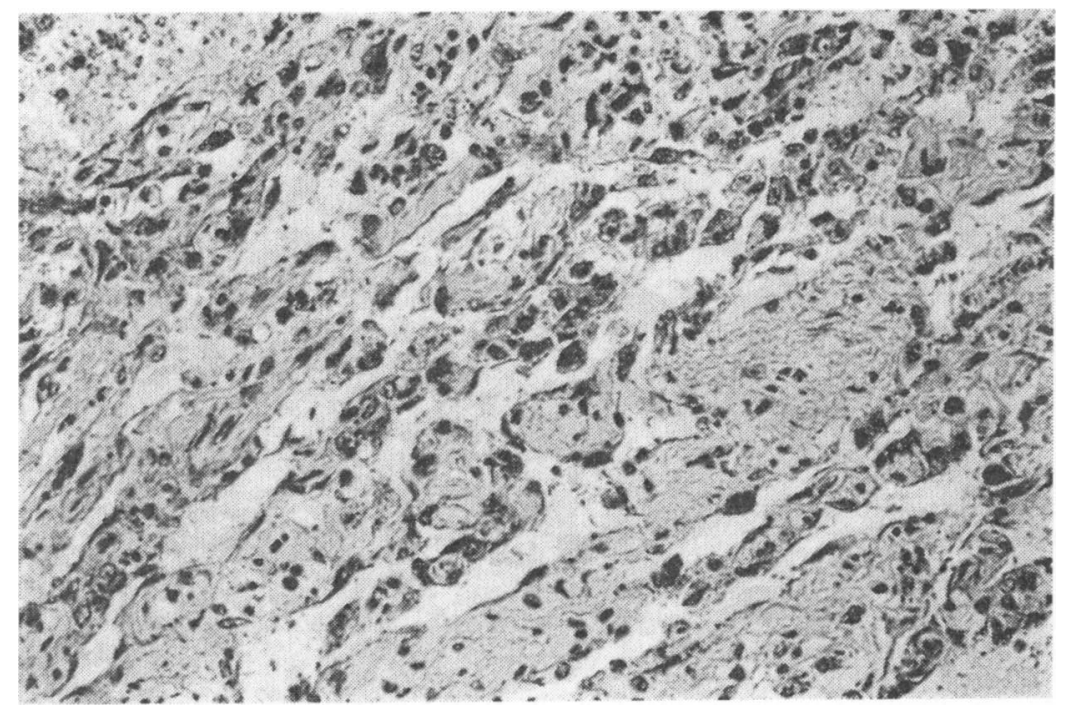

F i g u r e 2. (0.314/62). Well developed irregular blood vessels with, in some places, a collagenous fibrous stroma. Myocardium, dog. H-E. $\times 300$. 
with blood had formed (Fig. 2); these were surrounded by mostly fairly broad streaks of tumour cells in profuse connective tissue. In its peripheral and infiltrated parts the tumour was immature and lacked formed vessels, while a reduction of connective-tissue stroma had also occurred. Abundant haemosiderin deposits were also seen in the tumour tissue.

Postmortem diagnosis: Ruptured haemangioendothelioma of the heart; heart tamponade.

\section{Case 2}

Alsatian, $\sigma^{x}, 10$ years old. He fell ill on Jan. 1, 1963, with symptoms of tiredness and anorexia; but he took some food and fluid. At examination on Jan. 4 at the medical clinic of the Veterinary College he was highly anaemic and dehydrated, and treatment by administration of blood and fluid was started at once. Examination also showed prostatic enlargement and a mass in the abdominal cavity, which was judged as probably involving the spleen. His temperature was $39^{\circ} \mathrm{C}$. $\mathrm{X}$-ray examination showed widely scattered growths in the lungs but no definite evidence of changes in the abdominal cavity. A bloodtest showed anaemia $(\mathrm{Hb} .7 .0 \mathrm{~g}$ per $100 \mathrm{ml})$ and leucocytosis $(22.900$ cells per $\mathrm{mm}^{3}$ ). As the prognosis was regarded as poor, the dog was killed.

Autopsy (0.14/63) on Jan. 17, 1963: The dog was in a good state of nutrition (weight $37.5 \mathrm{~kg}$ ) and had moderate generalized anaemia. The lungs were studded with multiple relatively well defined, dark-red neoplasms, up to the size of a pea, of fairly soft consistency and moist disintegrating greyish-red to dark-red section surface. The lungs were also moderately oedematous. In the right auricle of the heart the wall was diffusely thickened by tumour, pale-red, and of soft loose consistency. The mitral valves were nodulated and fibriously thickened at their free margins. The spleen was slightly swollen; its borders were rounded and in the ventral third there were two neoplasms protruding slightly over the surface, approximately the size of hazelnuts, with dark-red homogeneous section surfaces and of the same soft consistency as the rest of the organ. In the liver were seen a few widely scattered new growths, up to the size of a hen's egg, frequently bulging over the surface, relatively well defined, of soft consistency, and with disintegrating reddish-grey to dark-red section surfaces rich in blood. In the cortex of both kidneys there were multiple diffusely scattered, fairly well defined, growths, the largest ones being double the size of a pea, in appearance resembling those described earlier. There was also moderate hypertrophy of the prostate and, as a result of this, dilatation of the urinary bladder and hypertrophy of the bladder wall.

Histological examination: $\mathrm{H}$ e a $\mathbf{r}$. The tumour showed the picture of a haemangioendothelioma with infiltrative growth. The tumour tissue was homogeneous throughout and formed irregular, more or less clearly marked, fibrous streaks covered with neoplastic endothelium. The spaces between these streaks were often empty or con- 


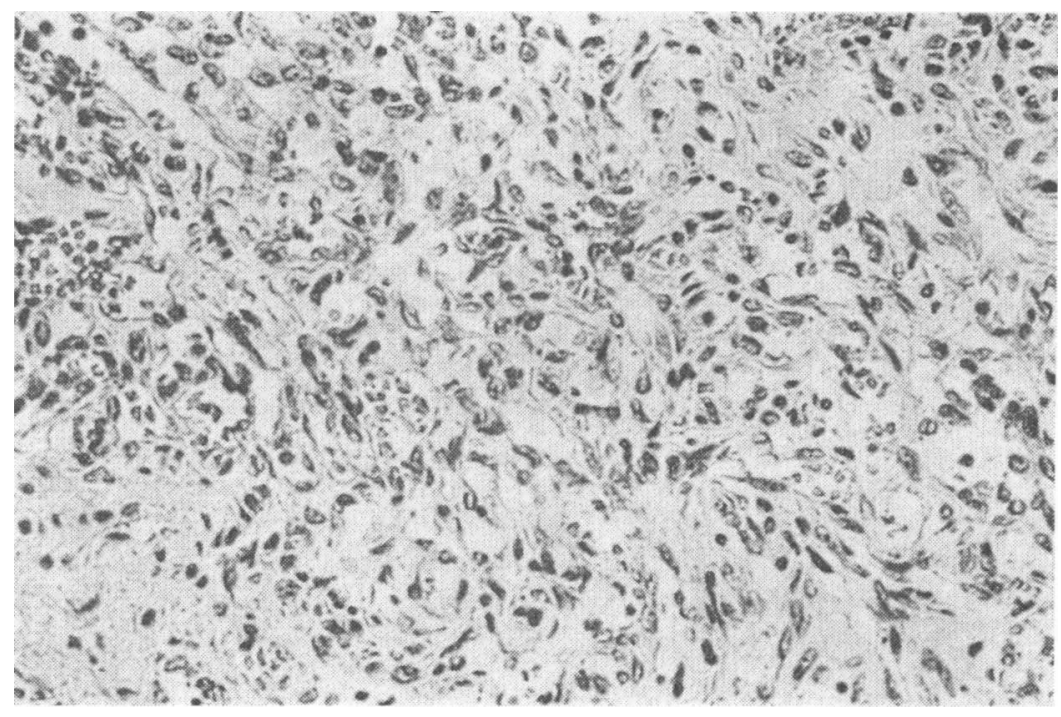

F i g u re 3. (0.14/63). Immature fibrous tissue with a tendency to form vascular spaces. Lung, dog. H-E. $\times 300$.

tained some erythrocytes. The tumour cells were of elongated, irregular shape and contained accentrically placed, large, pale, ovoid or slightly angular, nuclei, some of which had a fairly large faintly eosinophilic nucleolus. There was also some hyperchromatosis of the nuclear wall. In a few areas bone formation was seen in the connective tissue stroma, and there were foci of marked haemosiderosis with presence of phagocytizing cells. In its central parts the tumour showed some regressive changes.

L u n g. Multiple haemangioendotheliomas, most of which were well demarcated from the lung tissue. The smaller ones were of relatively homogeneous structure and interlaced with narrow fibrous streaks lined with neoplastic endothelium (Fig. 3). The spaces between them contained varying amounts of erythrocytes. In the larger tumours bloodfilled cavities had formed, and in the central parts of some of them regressive changes were seen and occasionally also bone formations in the connective tissue stroma.

$\mathrm{L}$ i ve r. Haemangioendotheliomas with infiltrative growth, showing regressive changes. The tumours were of slightly varying appeararance, like those in the lungs. In some of them there were large bloodfilled cavernous spaces lined with fairly thin layers of neoplastic endothelium, others formed more compact masses in which a tangle of fibrous streaks with tumour cells was seen in the tissue. Sparse amounts of blood occurred here. In some of these areas the tumour cells seemed to be undifferentiated and in appearance and arrangement they resembled, to some extent, fibrosarcomas. 
$\mathrm{K}$ i d n e $\mathrm{y}$. In the cortex there were large blood-filled cavernous spaces, which were separated from the renal tissue by thick connective-tissue capsules. Inside these a layer of neoplastic endothelium of varying thickness was seen, in some places projecting stepwise into the blood-filled cavity. The renal tissue around the tumours was the seat of atrophy.

Postmortem diagnosis: Metastasizing haemangioendothelioma of the right auricle of the heart.

\section{Case 3}

Boxer, $q, 9$ years old. She was admitted to the surgical clinic of the Veterinary College on May 5, 1965. She had then been ill for 2 weeks with extreme weakness, breathing difficulties, and abdominal distension. Her general condition had deteriorated gradually, and on admission it was very poor. The clinical examination showed markedly anaemic mucous membranes and blood in the abdominal cavity. At laparotomy on the same day multiple growths were seen in the abdominal cavity, and therefore the dog was killed.

Autopsy (0.319/65) on May 6, 1965: The dog was in a medium state of nutrition (weight $26.5 \mathrm{~kg}$ ), and had marked anaemia. In the lungs there were a few pale-red, well defined, round neoplasms, up to the size of half a pea, of a cyst-like appearance with a thin palegrey capsule and filled with non-coagulated blood. The lungs were also markedly oedematous. In the wall of the left chamber of the heart were seen a few small semi-transparent pale-grey areas of softening of the myocardium which were very poorly defined. The abdominal cavity contained about $1 / 2 \mathrm{l}$ of blood, and between the right kidney and the anterior pelvic border there were two well defined tumours, about double the size of a hen's eggs, with pale-grey capsules and a dark-red to greyish-red haematoma-like interior and which seemingly had arisen in the peritoneum. In other parts of the peritoneum, notably in the network, there were a very profuse amount of similar tumours, the largest being just over the size of a hazelnut; they were cyst-like in appearance, with a content that in many of them consisted of relatively thin blood, and had a red-grey to dark-red wall, about $1 \mathrm{~mm}$ thick. In some places the tumours had become merged, and frequently they were seen to be pedunculated (Fig. 4). In the ventral half of the spleen there were two reddish-black tumours, about double the size of hazelnuts, which bulged out beyond the section surface, of soft consistency and a glistening somewhat mottled, reddish-black and greyish-red, slightly bulging cut surface. The kidneys were also the seat of chronic nephritis; they were of firm consistency and showed numerous fairly marked, pale-grey, irregular scars, to which the renal capsules were strongly adherent.

Histological examination: The tumours involving the peritoneum consisted of streaks of tumorous endothelium in very sparse connective-tissue stroma and formed an irregular pattern in the tissue. In these narrow spaces filled with erythrocytes had formed, and between the streaks of tumorous tissue large cavities filled with blood were 


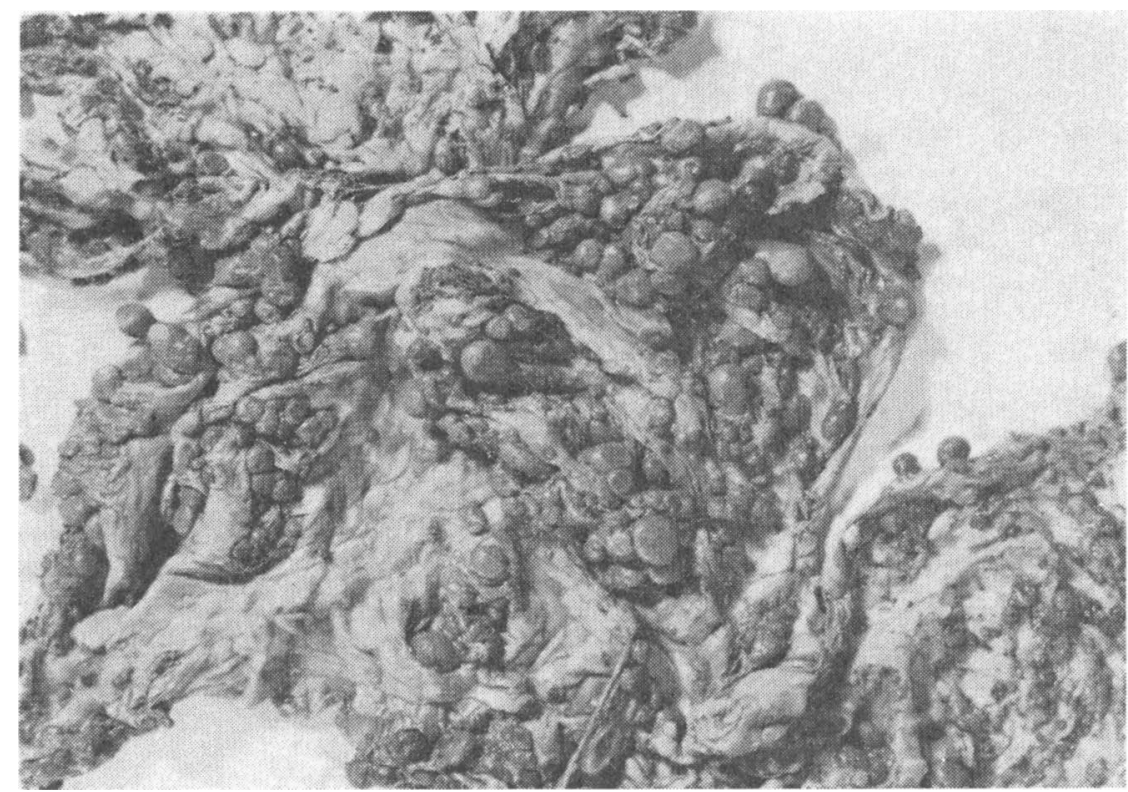

Figure 4. (0.319/65). Multiple haemangioendothelioma in the omentum of a dog. The tumours are well demarcated and pedunculated.

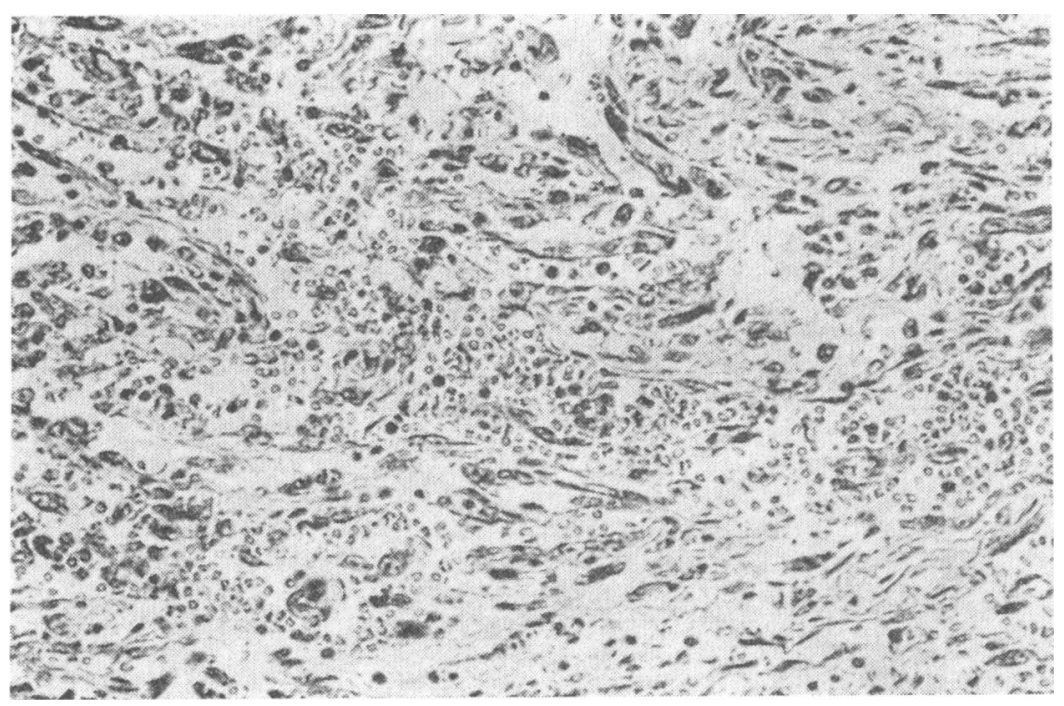

Figu re 5. (0.319/65). A sparse connective-tissue stroma with irregular spaces containing erythrocytes. Spleen, dog. H-E. $\times 300$. 
seen. The tumours were well defined, and the largest ones consisted mainly of a haematoma, surrounded by a connective-tissue capsule, which in some areas was quite thick and inside which there was a fairly narrow zone of tumour cells. These were slightly elongated and had ovoid, round, or slightly angular nuclei in many of which the chromatin accumulated at the nuclear wall and which occasionally contained relatively large, faintly eosinophilic nucleoli.

S p l e e n. Mostly fairly well defined haemangioendotheliomas of the same structure as those in the peritoneum, but the blood-filled cavities were not as large (Fig. 5).

$\mathrm{L}$ u $\mathrm{n}$ g. Haemangioendotheliomas resembling those described in the foregoing. The connective tissue stroma, however, was slightly more profuse and the tumours seemed partly to infiltrate the surrounding lung tissue. This was also markedly oedematous, and in some of the larger vessels there were emboli of tumour cells.

My ocardium. Tumour of infiltrative type of growth, consisting of fairly sparse, mostly unevenly arranged, poorly differentiated tumour cells in a very loose connective tissue. The blastomatous cells were usually elongated and were almost filled with round, ovoid, or irregularly angular nuclei. Hyperchromatosis of the nuclear wall and large nucleoli were seen fairly often. In some places there was a tendency to formation of small ring-shaped groups resembling vessels. The newly formed vessels contained sparse amounts of erythrocytes.

Postmortem diagnosis: Metastasizing haemangioendothelioma of the peritoneum.

Of our 49 dogs with haemangioendothelioma 36 were males and 13 were bitches, and the ages of 47 of them ranged from 6 to 13 years with a mean age of 9.5 years. For the sake of comparison, it should be mentioned that out of the total number of dogs subjected to autopsy at the Institute during the same period of time $(12,635$ cases $), 50.2 \%$ were males and $49.8 \%$ were females. The mean age of these were 4.9 years (Fig. 6).

The period of illness observed by the owner varies quite considerably. Four of the animals died under dramatic circumstances without having shown any symptoms at all previously, and 3 had shown symptoms of disease for 1 or 2 days. A period of illness of $1-3$ weeks seems to have been most usual and had occurred in 23 animals. Eleven dogs had been ill for $1-2$ months and 4 had been more or less severely ill for more than 2 months. In 4 cases other diseases had concealed any symptoms that might have been due to the diagnosed tumours.

The predominant symptoms had been a poor general condition manifested by some drowsiness and weakness, as observed 


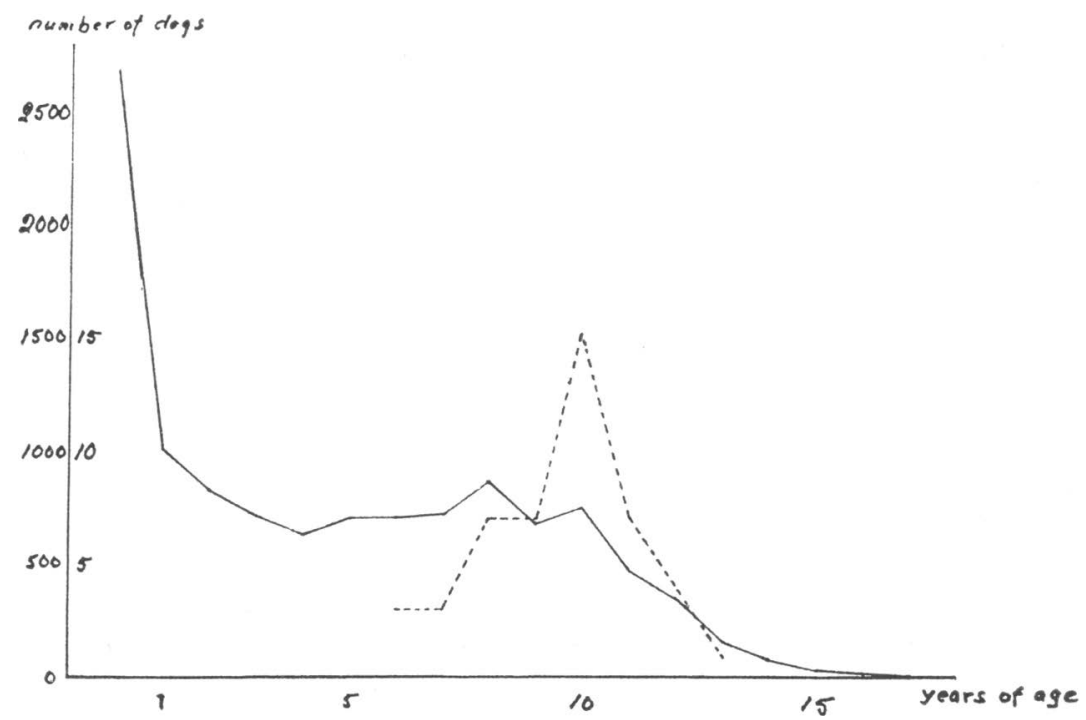

Figur e 6. Age distribution. The continuous line indicates the age distribution in the total number of autopsy cases. The broken line indicates the distribution of dogs with haemangioendothelioma.

in 45 of the cases. In some of these cases there occurred states of collapse, from which the dogs usually recovered fairly quickly, and between which they were seemingly in fairly good health. Out of 12 dogs for which temperature data from the period of illness are available, 11 had fever, with temperatures between 39 and $40^{\circ} \mathrm{C}$. The highest temperature measured was $40.3^{\circ} \mathrm{C}$. Dyspnoea, rattles, and other breathing disorders were reported in 11 cases. Eight dogs had a cough, in 2 of them attended with expectoration of blood-stained matter. Ten dogs were reported to have been shown increased thirst.

Only in 7 cases could the tumour be palpated or seen clinically and in many cases the diagnosis was made by X-ray or at laparotomy.

Blood tests are reported in 15 cases and 10 of these had abnormally high leucocyte counts, ranging between 16,000 and 58,500 cells per $\mathrm{mm}^{3}$. One dog had leucopenia (3500 cells per $\mathrm{mm}^{3}$ ) and 4 had normal leucocyte counts. Lymphocytosis was present in 1 case; the rest had normal values.

Both $\mathrm{Hb}$ and erythrocyte counts were in all examined cases below normal, the values ranging from 3.2 to $12.5 \mathrm{~g}$ per $100 \mathrm{ml}$ and from 18,000 to 43,000 cells per $\mathrm{mm}^{3}$, respectively. 


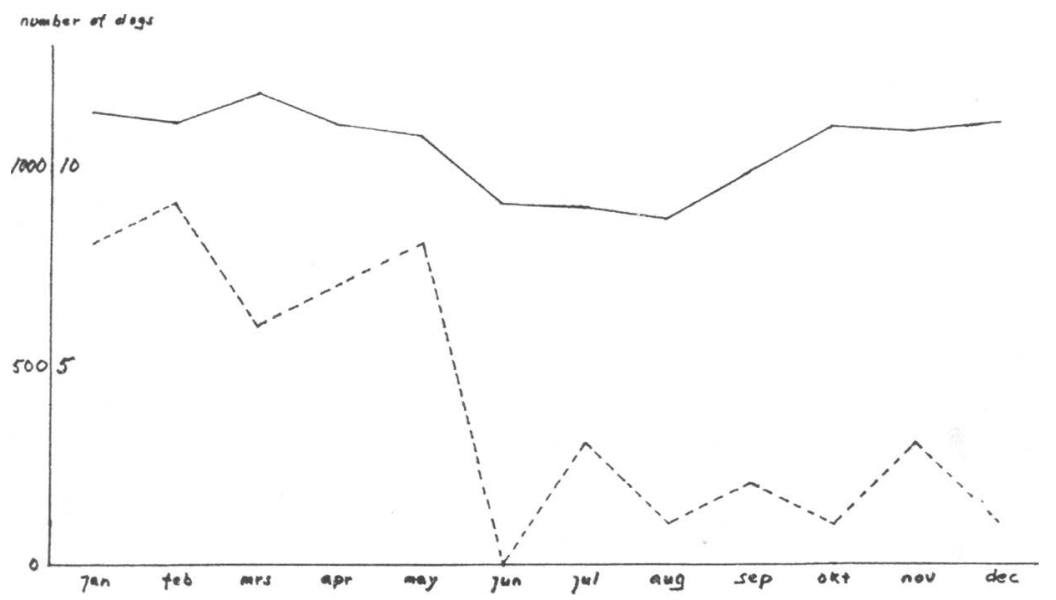

F ig u re 7. Number of dogs subjected to autopsy over the 26-year period $1940-1965$, distributed by months. The broken line indicates dogs with haemangioendothelioma.

Other blood values and the results of the urine tests that were made showed no noteworthy deviations from the normal. The found values were compared with the normal values for dogs given by Paulsson \& Ảberg (1965).

Out of the dogs in our series, $38(77.6 \%)$ fell ill and were subjected to autopsy during the period January to May, whereas the other 11 cases occurred in the months of July to December. Thus, there is a distinct increase in the incidence during the first five months of the year, which is not in accordance with the figures for the total number of autopsy cases over the 26 years concerned (Fig. 7).

Fifteen breeds are represented in our haemangioendothelioma series which, in addition, includes 4 mongrel dogs (Table 1 ).

The number of organs involved in each individual varies. Four dogs had tumours in only one organ; 2 of them had a tumour of the heart and $\mathbf{2}$ had multiple tumours in the lungs. Two organs were involved in $11 \mathrm{dogs}$, and the rest (34 dogs) had tumours in three or more organs.

In 39 cases of tumours in more than one organ we believe that we were able to establish the localisation of the primary tumour, and the frequency of involvement of the various organs will be seen from Table 2. 
T a b l e 1. Breed distribution of the dogs.

\begin{tabular}{lc}
\hline Breed & No. of cases \\
\hline Alsatian & 21 \\
Boxer & 7 \\
Poodle & 2 \\
Dachshund & 2 \\
Pomeranian & 2 \\
Spaniel & 2 \\
Airedale terrier & 1 \\
Welsh terrier & 1 \\
Irish terrier & 1 \\
Irish wolf-hound & 1 \\
Chow-chow & 1 \\
Rottweiler & 1 \\
Vorsteh & 1 \\
Schnauzer & 1 \\
Greyhound & 1 \\
Mixed breed & 4 \\
\hline
\end{tabular}

T a b l e 2. Frequency of tumours in various organs.

\begin{tabular}{lrrc}
\hline \multicolumn{1}{c}{ Organ } & Number & $\%$ & $\begin{array}{c}\text { Primary } \\
\text { growth }\end{array}$ \\
\hline Lung & 37 & 75.5 & $(2)$ \\
Heart & 32 & 65.3 & 22 \\
Liver & 24 & 48.8 & 4 \\
Peritoneum & 23 & 46.9 & 5 \\
Spleen & 19 & 38.8 & 5 \\
Kidney & 15 & 30.6 & 1 \\
Skeletal muscle & 9 & 18.4 & \\
Subcutis & 6 & 12.2 & 1 \\
Pleura & 6 & 12.2 & \\
Brain & 5 & 10.2 & 1 \\
Spinal medullary canal & 2 & 4,1 & \\
Vertebra & 1 & 2.0 & \\
Bone marrow & 1 & 2.0 & \\
Prepuce & 1 & 2.0 & \\
Intestine & 1 & 2.0 & \\
Pancreas & 1 & 2.0 & \\
\hline
\end{tabular}

The tumours involving the lungs (37) were in most cases multiple and scattered over the whole organ. They were seldom larger than the size of a hazelnut and were mostly of spherical or cyst-like shape with a fairly thin pale-grey capsule and had a content consisting of well or poorly coagulated blood. Haemo- 
thorax was present in 4 cases of lung metastases, although rupture of any tumour could not be demonstrated.

It will be seen from Table 2 that haemangioendothelioma of the heart occurred in 32 cases, and the distribution of the tumours by localisation in the heart was as follows:

Right auricle 14, left ventricular wall 9, right ventricular wall 7, right atrium, excluding auricle, 6, ventricular septum 5, and left auricle 2 cases.

Ten dogs had more than one tumour in the heart. Haemopericardium was present in 8 cases, having the character of heart tamponade in 6. Almost without exception, the tumours in the heart were very indistinctly outlined against the myocardium, and in many cases there was diffuse infiltration of the wall involving its entire thickness, which sometimes made it rather difficult to discover the tumour. Most of the tumours were of hazelnut size, but even larger ones were found. The colour of the tumours varied from pale-red to dark-red and many of them were of loose consistency. Because of profuse haemorrhages inside the tumours, many of them were seen to bulge out beyond the epicardium or endocardium, and in those cases in which there were haemorrhages into the pericardium one or more very small ruptures in the tumour capsule or complete rupture of a tumorous atrial wall were seen (Figs. 8 and 9).

Tumours in the liver were found in 24 cases, and in most of these they were multiple and widely scattered. Only in 1 case a solitary tumour was found in the liver. Because of profuse haemorrhages inside the tumours they were often of considerable size, some being as large as a fist. The tumours were dark-red and of fairly soft, slightly variable, consistency; on the cut surface a network of pale-grey tumour tissue appeared, and in the interspaces there were blood-filled cavities of varying size. In 4 cases one or several tumours had ruptured, and in another 4 cases liver tumours were combined with haematocoelia but without any demonstrable rupture.

The tumours involving the peritoneum ( 23 cases) were often fairly diffusely spread. The most common site was the network, (15 cases), followed by the parietal peritoneum (8 cases), the mesentery ( 6 cases), and the broad ligaments of the uterus (3 cases). Tumours also occurred subserously in the intestine (2 cases), the ovary ( 1 case), the umbilical fold ( 1 case), and periurethrally ( 1 case). All the said tumours were well demarcated, 


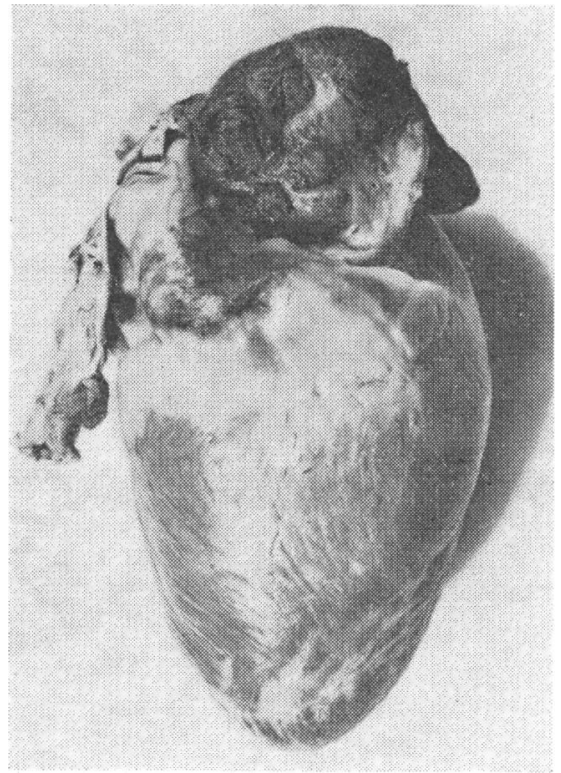

F ig u r e 8. (0.106/55). Haemangioendothelioma in the right auricle of the heart in a dog. The heart greatly contracted because of heart tamponade.

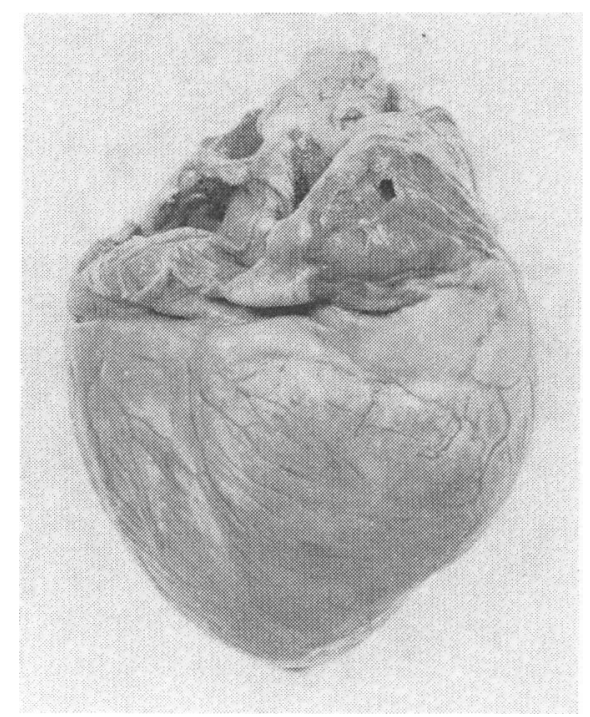

F i g u r e 9. (0.172/63). Rupture of the neoplastic wall of right atrium in a dog.

the largest being the size of a fist. Rupture of a tumour in the network was seen in 2 cases. Many of the tumours appeared more or less pedunculated, of fairly loose consistency, and with a mottled pale-grey and dark-red moist cut surface. Some were situated immediately beneath the peritoneum in the fatty tissue, and they were of extremely thin-walled haematoma-like appearance. In 1 case a tumour had broken through the bladder wall with haematuria resulting.

The spleen was involved in 19 cases. Among these, a solitary tumour occurred in 7, two tumours in 2, a few diffusely spread tumours in 4 , multiple widely scattered tumours in 6 cases. Some of the tumours were as large as a fist, and ruptures were seen in 3 cases. Macroscopically, the tumours in the spleen were fairly poorly circumscribed and slightly bulging out beyond the surrounding surface. They were mostly slightly firmer in consistency than normal splenic tissue, and the cut surface was fairly homogeneous and dark-red with grey streaks. In those cases, in 
which the entire spleen was involved, the organ was much enlarged (up to $0.8 \%$ ). No preferential site of the tumours in the spleen was evident in our series. In 4 cases a neoplastic spleen was removed by surgery within 2 months before autopsy, but, unfortunately, only one of them was examined histologically and, being a haemangioendothelioma, it has been included in this statistical analysis.

The kidneys were affected in 15 cases. Among these, the tumours involved both kidneys in 10 and only. one kidney in 5 cases. In the latter the tumour was located in the right kidney in 3 and in the left kidney in 2 cases. The tumours were solitary in 3 cases and multiple in the rest. They were located in the cortical zone in 10 cases; information about the site is lacking in the rest. Most of the tumours were the size of a pea, but in 1 case they were $4-5 \mathrm{~cm}$ in diameter. In every case they showed some degree of disintegration and most of them were poorly circumscribed. When all the blood had escaped after cutting through the tumours, there remained a delicate collapsed mesh-work of tumour tissue.

Tumours in the skeletal muscles occurred in 9 cases, the most common sites being the muscles of the back, shoulder, and neck. The size of the tumours varied from a few $\mathrm{mm}$ to $5-6 \mathrm{~cm}$ in diameter. Both poorly and well demarcated tumours occurred, but the former predominated. Because of very thin capsules, many of them had burst and appeared as diffuse elongated areas of haemorrhage in the muscle, and in places of profuse occurrence they had merged together, sometimes forming quite large areas. In 1 case direct encroachment by a tumour in a vertebra had occurred.

Tumours in the subcutaneous tissues occurred in 6 cases. With the exception of 1 case of multiple tumours, most were cases of solitary tumours, which were usually spherical in shape and well encapsulated. In 3 of the cases they were located in the shoulder and neck region, while in the rest they were widely scattered. A particularly common site was the subcutaneous fat.

The tumours in the pleura were located in the parietal pleura in 6 cases, with simultaneous involvement of the mediastinurn in 2 , and in the pericardium in 1 case. In half the cases the tumours were very numerous, and in the rest they were solitary. They were of the same appearance as those in the peritoneum, being well circumscribed and often more or less pedunculated. 
In 4 of the cases tumours were also found in the lungs. Haemothorax was present in 2 cases.

Tumours occurred in the brain in 5 cases. They were spherical and filled with blood and usually well encapsulated by very thin tumour tissue. Most of them were the size of peas, but sizes of up to $2-3 \mathrm{~cm}$ in diameter were seen. The cerebrum was the seat of tumours in all the cases; the cerebellum, brain-stem, and the respective meninges were also involved in 3 cases. The tumours were multiple in 3 cases and solitary in the rest. None of these dogs had exhibited any nervous symptoms that could be referred to the tumours.

The spinal cord was the seat of tumours in 2 cases. In 1 case they were located in the posterior part around the cauda equina and were double the size of a pea; the other one was a case of direct encroachment from a tumorous vertebra (see below).

A poorly circumscribed pea-sized metastatic tumour in the bone marrow was seen in 1 case. It was located in the upper part of the left humerus and involved mainly the fatty tissue in the bone marrow.

Bony tissue was affected in 1 case, with involvement of the greater part of a vertebral body (L 5). The tumour encroached on and infiltrated the adjacent tissues (see above).

A pea-sized tumour was found in the prepuce in 1 case, and multiple tumour metastases were seen in the pancreas and the jejunum in 1 case, respectively. Those in the jejunum were poorly circumscribed confluescent tumours situated in the tunica muscularis.

T a b l e 3. Frequency of different autopsy findings.

\begin{tabular}{lc}
\hline Autopsy findings & No. of cases \\
\hline Generalized anaemia & 19 \\
Other tumours & 17 \\
Haematocoelia & 12 \\
Haemopericardium & 8 \\
Acute stasis of the liver & 8 \\
Chronic interstitial nephritis & 8 \\
Hydrothorax & 6 \\
Haemothorax & 6 \\
Jaundice & 6 \\
Ascites & 5 \\
Hypertrophy of heart & 4 \\
\hline
\end{tabular}


Other important autopsy findings were distributed as seen in Table 3.

Among the 19 cases in which severe anaemia was diagnosed at autopsy, 13 had had haemorrhages into the abdominal cavity, chest, pericardium, or muscles. In the other 6 cases there were no findings of such bleeding that could have explained the anaemia.

Other tumours were also found at autopsy in 17 cases, namely lymphoma of the spleen in 5, seminoma in 4, carcinoma of the thyroid in 2, leiomyoma in 2, and fibroma, lipoma, and haemangioma in 1 case each. One dog was also found to have two other types of sarcoma, namely giant-cell sarcoma and melanosarcoma.

In half the cases in which it was present, haematocoelia was associated with visible rupture of an abdominal tumour, and 6 of the dogs with haemopericardium had concurrent hepatic stasis.

Haemothorax was referable to rupture of a tumour in only 1 case.

Jaundice was in 5 out of 6 cases referable to widespread tumours and profuse bleedings (prehepatic jaundice) and in 1 case to liver cirrhosis.

In all but one of the dogs which displayed effusion into serous cavities the heart was affected by the tumour.

Chronic interstitial nephritis and other autopsy findings not listed here were among those frequently made in dogs of this age-group.

The histological picture varied with the degree of maturity. There were cases in which the tumour cells were of very low degree of differentiation with no or very weak tendency to formation of vessels. These tumours usually contained no or very few erythrocytes. Others, again, were more highly differentiated and formed large blood-filled cavities and channels surrounded by a tumour-cell layer of varying thickness. Between these two extremes there were intermediate forms, which displayed an extensive and irregular network of usually fairly narrow streaks of tumorous endothelium between which, in small narrow spaces and channels, were often seen great amounts of erythrocytes and immature forms of such cells. It was not unusual for the same tumour to show divers forms of differentiation. Central necrosis of the tumour tissue was also seen sometimes. 
The tumour cells were elongated and irregular with round, ovoid, or occasionally slightly angular, large nuclei, which were fairly rich in chromatin, eccentrically placed, and frequently contained one or two large faintly eosinophilic nucleoli, some of which had assumed an inclusion-like character. Hyperchromatosis of the nuclear wall was also seen very often. The cell nuclei appeared to be completely empty, except for a demonstrable nucleolus in some instances.

The tumour stroma consisted generally of very sparse and loose connective tissue, but were in some places virtually absent and in others very profuse. In the latter cases, hyalinization of the connective tissue stroma was fairly common, and ossification was also seen.

Tumours with well developed vessels often displayed haemosiderosis, which sometimes wes very pronounced and often accompanied by profuse numbers of phagocytizing cells. Polynuclear giant cells were seen in only 2 cases, however.

The tumours in the myocardium, skeletal muscles, smooth muscle, kidney, bone, and bone marrow showed, almost without exceptions, a highly infiltrative growth, while those in other organs included both infiltrative and well demarcated types. The latter predominated in some organs, such as the peritoneum, pleura, brain, and lung.

Growth into and tumour-cell emboli in blood vessels were seen in some cases, particularly in the lungs. These emboli sometimes contained fairly large amounts of tumour cells.

\section{DISCUSSION}

The disease usually ran a fairly rapid and accelerating course, and in the 17 dogs, which died a natural death, the direct cause of death seems to have been anaemia due to blood loss or shock due to heavy bleedings from the tumours or into serous cavities, and heart tamponade. Most of the other dogs were in very poor condition at the time of killing, however, and would probably have died within the next few days. In published reports the duration of the disease varies from a few days (Lieberman 1955) to 3 or 4 months (Pounden \& Sprunger 1947, Farrel \& Farrel 1960). Brandt \& Sofrenovic (1963), and Brodey (1964), in a series of 9 cases of extirpation of the spleen with haemangioendothelioma, report survival times between 2 weeks and 3 years; 
most of the dogs, however, did not survive 4 months. In most reports the direct causes of death are not stated, but from the descriptions it seems evident that they agree with those found in our cases.

The most prominent clinical symptoms of haemangioendothelioma described by earlier authors are generalized weakness and anaemia, dropsy and bleedings into serous cavities, and jaundice (Mason 1960, Brandt \& Sofrenovic, Brodey), as was also found in our investigation. Some of the other symptoms and clinical findings which have been reported here can be explained by the spread and location of the tumours, while others seem to be more unexpected. The increased thirst in some cases, for instance, would be attributable to the profuse bleedings which always occur inside and outside the tumours. Breathing difficulties and cough were present in dogs with tumours in the lungs and heart and, similarly, the heart was affected in most of the dogs with accumulation of fluid in serous cavities. Symptoms more difficult to explain are the elevated temperature and the leucocytosis noted in most of the animals that were examined in these respects. Usually, the temperature rise is in such cases attributed to the metastatic spread, but it may be advisable not to exclude the possibility that the character of the tumours may play a part in this respect. Bacteriological examinations were not made in our cases.

Another observation which is difficult to explain is the periodicity that was noted in the onset of illness and the admission of these cases (Fig. 7). During the 26 years covered by the investigation most of the dogs $(77.6 \%)$ where sent for autopsy in the period January-May. In view of the total number of autopsies over the same period of time, the expected frequency is $44.8 \%$. So, here is a highly significant difference $\left(\chi_{\mathrm{c}}^{2}=19.0, \mathrm{P}<0.0005\right)$ which we are not able to explain.

A statistically significant difference was also found with respect to the preponderance for the male dogs in the sex distribution $\left(\chi_{\mathrm{c}}^{2}=9.7, \mathrm{P}<0.005\right)$ and from a perusal of the earlier reports and compilations of haemangioendothelioma in dogs it appears that there, too, the majority were male dogs, as has also been emphasized by Mulligan (1963).

Similarly, there seems to be an increased tendency to the development of haemangioendothelioma in the higher age groups (Fig. 6). The mean age in our series is 9.5 years, and none of 
the dogs was younger than 6 years of age. This age disposition is recognized throughout the earlier literature, both for haemangioendotheliomas and for tumours in general. There are reports, however, of dogs affected at the age of 1.5 years (Mason) and 3 years (Pounden \& Sprunger). Moulton (1961) gives the age of 8 years or older, but states that it can be as low as 3 years.

From our cases it is evident that the Alsatian, but also the Boxer, is represented more frequently than other dogs (Table 1). The predisposition to tumours in the Boxer has been mentioned by several authors, although all of them do not present any statistical evidence. It has been found that this breed is more frequently than others subject to glioma (Hjärre 1938), heartbase tumours (Nilsson 1955), and mastocytoma (Köhler 1956, Larsson 1957). On the basis of the material of tumours in dogs from this department covering a period of 17 years, Krook (1954) has proved statistically that the Boxer is more liable to develop carcinoma than any other breed. In recent years, the Alsatian has also been stated to be predisposed to tumours (Haanagel 1959, Garlt \& Rössger 1960, Müller 1964). However, most of the statistical analyses concern tumours in general and comparisons between the predisposition to sarcoma and carcinoma, respectively. Varying results have been obtained, but the main impression is that both the Boxer and the Alsatian occupy a prominent place in tumour statistics.

The 21 Alsatians among our cases represented $42.9 \%$ of the series. The frequency of this breed in the total number of autopsies over the same period of time is $10.5 \%$, and a comparative $\chi^{2}$ analysis of these values shows a very high significance $\left(\chi_{c}^{2}=51.9\right.$, $\mathbf{P}<0.0005$ ). As regards the Boxer, which in our series represents $14.3 \%$ and in the total number of autopsies $6.2 \%$, the value is almost significant $\left(\chi_{\mathrm{c}}^{2}=4.4, \mathrm{P}<0.05\right)$.

As to site (see Table 2), we found tumours most of ten in lung, heart, liver, and peritoneum. Corresponding data in the literature show some deviations. The most common site is, according to Mason and Brodey spleen and liver, according to Jubb \& Kennedy (1963) spleen and heart, according to Moulton spleen and skin. according to Smith \& Jones (1957) spleen and subcutis, and according to Mulligan (1963) spleen, retroperitoneum, and perineum. Other organs have also been mentioned, but these have been represented to a much smaller extent; they include lung, heart, muscle, peritoneum, and brain. Mason, in his series of 22 
cases, presents some 20 different sites, but in many cases it is not clear in what organ the tumour was located. Moulton (1961) states that spread to regional lymph glands is also common, but we found no evidence of this in our cases.

In all our cases of lung involvement, the tumours occurred multiply and in very great numbers, which would explain their character of metastases. In all the cases except two, primary tumours, usually located in the heart, were also found. As the haemangioendotheliomas in the right atrium are usually poorly circumscribed and, especially between the trabeculae in the auricle, not very easy to discover, a tumour at this site can have been present in these two cases, though it was not detected.

Data on the location of the tumour within the various organs are very sparse. $J u b b \&$ Kennedy consider that in the spleen it is the ventral part and in the heart the proximal portion of the right ventricle (conus arteriosis). Lieberman reports a case with haemangioendothelioma of the heart and lungs, where the tumour in the heart was located in the right atrium. This latter observation seems to accord with our results, namely that the right atrium, and particularly the right auricle, would be the place especially susceptible to this type of tumour when involving the heart. This location of the tumour is also manifested by the presence of lung metastases in all these cases but one.

The right auricle of the heart seems to be the primary site of different mesenchymal tumours in animals. Besides the haemangioendothelioma - we see it in the fibroma (Magnusson 1961) and the leukotic changes of cattle (Järplid 1964). In human beings cardiac sarcomas generally arise in the right atrium or auricle (Hurst \& Cooper 1955) too.

Most of the tumours involving the kidneys were situated in the cortex, and this is also the most highly vascular portion of the organ. As regards skeletal muscle and brain, a certain predeliction could be noted, namely for the muscles of the back, shoulders and neck, and the cerebrum, but the number of cases is too small to allow any definite conclusions. Equally, no distinct location could be established in the other organs, and in most of these the tumours were multiple.

Some skeletal parts, such as vertebrae, humerus, and femur, were sawed through for examination, and tumours were found in only 2 cases (in the humerus and a lumbar vertebra, respectively). 
The rest of the most common autopsy findings have been discussed under clinical symptoms.

17 of the dogs had one or several tumours of other types. These were usually benign and, as many of the dogs were old, their presence would depend on the increased susceptibility of aging tissue to the development of tumours.

Acute stagnation of the blood in the liver and effusion of fluid into serous cavities may be assumed to be associated with the presence of cardiac insufficiency. It is also possible that beginning insufficiency in not yet neoplastic endothelium may have given rise to some transudation.

The jaundice that was present may be interpreted as being prehepatic jaundice, a quite natural result of the extremely numerous haemorrhages which accompany these tumours. Becker \& Büsscher (1961), in a compilation of 85 cases of primary haemangioendothelioma of the liver in man, state that jaundice occurred in 33 cases and that it usually developed in the later stages of the disease. Liver function tests were also normal in most of their cases.

The histological picture of these tumours is consistent with what has been described earlier in this field (Feldman 1932, Mulligan 1949, Mason, Moulton, Järplid 1961). Mason divided his cases into four histological groups, but they seem to represent the varying degrees of differentiation which usually occur and which are often seen within the same tumour.

Ossification of the tumour stroma, which was noted in some of our cases, has not been described earlier. We seem to be concerned here with metaplastic transformation of the tumour stroma, as found in epithelial tumours of the udder in dogs and in cancer of the colon in horses (Rubarth 1934). Haemosiderosis with accompanying occurrence of macrophages seems to be very common in the tumours. The presence of giant cells in the domestic animals, however, has earlier been mentioned only by Mason.

The malignancy of these tumours seems to be extremely high and the haematogenic spread very rapid and effective. This is also borne out by the infiltrative growth, which is often very clearly visible macroscopically. 


\section{OBSERVATIONS IN HORSE AND CATTLE}

In addition to the 49 dogs reported here, autopsies of 2 horses and 2 cows which died from haemangioendothelioma were also performed at the Institute during the period concerned. As the literature contains very few reports on such cases and as ours are only 4, we will describe each one separately.

\section{Case 1.}

A horse; American trotter, $\sigma^{x}, 4$ years old. He fell ill on Dec. 3, 1950, with a swelling, the size of a football and of sudden onset, underneath the abdomen immediately in front of the prepuce. At the same time he became very drowsy and apathetic and showed partial anorexia. Three days later a similar swelling appeared laterally on the right thigh on a level with the knee joint, and the horse died on the 6th day after onset. His temperature during the illness ranged between 38.7 and $39.7^{\circ} \mathrm{C}$. Blood tests showed leucocytosis $(16,000$ cells per $\mathrm{mm}^{3}$ ) and mild anaemia.

Autopsy (0.942/50) on Dec. 13, 1950: The horse was in medium state of nutrition and weighed $410 \mathrm{~kg}$. The carcass was highly jaundiced; there was subcutaneous oedema, in many places fairly marked. The clinically observed swellings were found to be haematoma-like tumours located in the muscles of the abdomen and thigh, respectively; in addition there were several similar growths, varying from the size of a pea to that of a walnut, fairly well defined, and scattered in the skeletal muscles as well as in the diaphragm. The heart contained one pea-sized and one walnut-sized tumour, situated in the left and the right parietal ventricular wall, respectively. These, too, resembled well-defined haematomas in appearance. Other findings were extensive areas of oedema and haemorrhages in several internal organs and, as a result of these, generalized anaemia.

The spleen was enlarged and hyperaemic (relative weight $0.54 \%$ ) and the liver was of a quite distinct pale-yellow colour with a marked lobular pattern.

Histological examination: The tumours situated in the heart and skeletal muscles were of similar appearance. The internal parts consisted mainly of large erythrocyte masses encapsulated by a fairly thick layer of tumour tissue. The latter consisted of irregular, often very narrow, connective-tissue streaks lined with neoplastic endothelial cells. In the inner parts the connective-tissue stroma was very scanty and in some places absent, while it increased towards the periphery and enclosed the tumour, forming a fairly thick connectivetissue capsule, in which small islands of tumour cells and rests of muscle were seen.

The liver showed slight, finely-globular, centrolobular fatty degeneration of the liver cells.

Postmortem diagnosis: Multiple haemangioendotheliomas in the skeletal muscles and myocardium. 
Case 2.

A cart-horse of the Ardennes breed, $\circ, 21$ years old. She was found dead in the pasture ground on June 23,1958 , without having exhibited any signs of disease.

Autopsy (0.639/58): The horse was in a medium state of nutrition and weighed $640 \mathrm{~kg}$. The carcass was markedly anaemic with slight subcutaneous oedema. The abdomen contained about 201 of poorly coagulated blood. Both in the parietal and the visceral peritoneum there were fairly numerous dark-red neoplasms, up to the size of a walnut, with a dark-red glistening section surface, and showing great amounts of blood-filled cavities. The tumours were of soft and disintegrating consistency. They occurred particularly abundantly in the mesenterium. Both ovaries were much enlarged and studded over with blood-filled cavities, up to walnut size. The right ovary was the seat of a rupture, about $2 \times 0.5 \mathrm{~cm}$ in size, at the edges of which were seen profuse amounts of blood clots. Other autopsy findings were hydrothorax and atrophy of the right liver lobe.

Histological examination: The tumours in the peritoneum and the ovaries showed the picture of haemangioendothelioma with cavernous spaces, which were often filled with blood and between which were seen narrow and wide irregular streaks of neoplastic endothelium in connective tissue which was very profuse, especially peripherally.

Postmortem diagnosis: Multiple haemangioendotheliomas in the peritoneum and ovaries, with rupture and fatal bleeding into the abdominal cavity.

\section{Case 3.}

A cow, S.R.B., $\circ, 11$ years old. She was found dead in her stall on the morning of Nov. 23, 1953. She had not shown any signs of disease, and in the previous evening she had appeared to be in good health.

Autopsy $(0.1032 / 53)$ on Nov. 24, 1953: She was in a medium state of nutrition, and marked generalized anaemia was noted. Centrally on the right flank, involving the abdominal muscles, there was a haematoma-like growth, about $5 \times 15 \mathrm{~cm}$ in size, which extended through the abdominal wall in its entire thickness. A rupture, $5 \mathrm{~cm}$ long, was seen in the abdominal cavity, which contained about 151 of partly coagulated blood. In the upper part of the spleen there was a similar haematoma-like growth with profuse subcapsular haemorrhages and a rupture, about $3 \mathrm{~cm}$ in length. The heart showed profuse subendocardial haemorrhages; no other noteworthy findings were made.

Histological examination: The haematoma-like growth situated in the spleen exhibited the picture of a haemangioendothelioma, forming thick fibrous streaks lined with neoplastic endothelium. The vessels thus formed were often seen to have collapsed and to lack blood. Numerous' areas of deposited haemosiderin were seen in the tumour tissue. The growth involving abdominal muscles could not be histologically proved to be a haemangioendothelioma. 
Postmortem diagnosis: Ruptured haemangioendothelioma in the spleen and haematoma in the abdominal wall with fatal bleeding into the abdominal cavity.

\section{Case 4.}

A cow, S.R.B., + , 7 years old. She was found dead on the morning of Nov. 17, 1954, after having appeared to be in good health the previous evening.

Autopsy (0.1176/54) was performed on Nov. 17, 1954. The cow was in a good state of nutrition. Marked generalized anaemia was noted. In the abdominal muscles of the right flank there was a haematoma, about $5 \times 5 \mathrm{~cm}$ in size, situated both subperitoneally and intermuscularly. In the right lobe of the diaphragm was seen a peasized, well-defined, grey-red, soft neoplasm, the section surface of which showed numerous haemorrhages. The abdominal cavity contained about 251 of partly coagulated blood. Centrally on the spleen there was a fairly well circumscribed grey-red tumour, about $5 \times 10$ $\mathrm{cm}$ in size, with an uneven surface and showing a great amount of blood-filled cavities. A rupture, about $7 \mathrm{~cm}$ long, of the capsule enclosing the tumour was seen in the posterior part. A similar, hazelnutsized, tumour was found in the dorsal portion of the spleen. The liver was diffusely studded over with fairly numerous similar tumours, up to the size of hazelnuts, of grey-red to dark-red colour and containing a great amount of blood-filled cavities. Other autopsy findings were subendocardial haemorrhages in the heart and a few areas of fatty degeneration in the liver.

Histological examination: The tumours located in the spleen, lungs, and liver were haemangioendotheliomas of similar appearances. They consisted of profuse amounts of irregularly arranged streaks of neoplastic endothelium, between which numerous erythrocytes were often seen. Large blood-filled cavernous spaces had formed centrally in the tumours. The tumour stroma frequently consisted of fairly abundant, occasionally also hyalinized, thick tissue, but was very scant in some parts. The haematoma situated in the muscles was, unfortunately, not examined histologically.

Postmortem diagnosis: Ruptured metastasizing haemangioendothelioma in the spleen; fatal bleeding to the abdominal cavity.

\section{REFERENCES}

Adamek, W.: Ùber die Blutgefässgeschwülste bei den Tieren. Inaug. Diss., Berlin 1934.

Becker, V. \& K. Büsscher: Über das Hämangioendotheliom der Leber. Acta hepato-splenologica 1961, 8, 356-379.

Brandt, H-P. \& D. Sofrenovic: Klinische Befunde bei Hämangioendotheliom des Hundes. Kleintier-Praxis 1963, 8, 227-229.

Brodey, R. S.: Vascular tumors of the canine spleen. Mod. vet. Pract. 1964, 45, 39—43, 46. 
Deiner, F.: Primäres Angiosarkom in der Leber eines Schweines. Diss. Hannover 1923.

Farrel, J. M. Jr \& D. Farrel: Hemangiosarkoma - a case history. Sth. West. Vet. $1960,14,61$.

Feldman, W. H.: Neoplasms of domesticated animals. W. B. Saunders Co. 1932.

Garlt, C. \& M. Rössger: Ein statistischer und kasuistischer Beitrag zur Geschwulsterkrankung beim Hund. Mh. Vet.-Med. 1960, 15, 153.

Haanagel, E.: UUber Hautkrankheiten bei Hund und Katze, mit besonderer Berücksichtigung der gutartigen Geschwulste. Inaug. Diss., Leipzig 1959.

Hjärre, A.: Förekomsten av gliom hos husdjuren. Nord. med. T. 1938, $15,352$.

Hurst, J. W. \& H. R. Cooper: Neoplastic disease of the heart. Amer. Heart J. 1955, 50, 782-802.

Jubb, K. V. F. \& P. C. Kennedy: Pathology of domestic animals. Academic Press, New York and London 1963.

Jungherr, E.: Tumors and tumorlike conditions in monkeys. Ann. N.Y. Acad. Sci. 1963, 108, 777--792.

Järplid, B.: Haemangioendothelium in poultry. J. comp. Path. 1961, 71, $370-376$.

Järplid, B.: Studies on the site of leukotic and preleukotic changes in the bovine heart. Path. Vet. 1964, 1, 366-408.

Krook, L.: A statistical investigation of carcinoma in the dog. Acta path. microbiol. scand. $1954,35,407-422$.

Köhler, H.: Zum sogenannten Mastozytom beim Hund. Schweiz. Z. allg. Path. 1956, 19, $249-258$.

Larsson, B.: Studies on canine mastocytoma. Thesis, Uppsala 1957.

Lieberman, L. L.: Malignant hemangioendothelioma of the canine heart. J. Amer. vet. med. Ass. 1955, 126, 296.

Lindsay, S. \& J. W. Gilmore: Primary splenic endotheliosarcoma in a dog. J. Amer. vet. med. Ass. 1946, 109, $194-197$.

Magnusson, G.: Primärtumoren im Herzen des Rindes. Dtsch. tierärztl. Wschr. 1961, 68, 405-409.

Mason, R. A.: Endothelial tumors in the dog. Thesis, Cornell Univ. 1960.

Mench, K.: Maligne Endotheliome in der Milz eines Pferdes. Berl. Münch. tierärztl. Wschr. 1936, 52, 4 -6.

Moulton, J. E.: Tumors in domestic animals. Univ. Calif. Press. 1961, 77-79.

Mulligan, R. M.: Neoplasms of the dog. William \& Wilkins, Baltimore 1949.

Mulligan, R. M.: Comparative pathology of human and canine cancer. Ann. N.Y. Acad. Sci. 1963, 108, 642-683.

Müller, D.: Beitrag zur Statistik der Tumoren beim Hund. Inaug. Diss., Hannover 1964. 
Nilsson, T.: Heart-base tumours in the dog. Acta path. microbiol. scand. 1955, 37, 385-397.

Paulsson, S. \& B. Åberg: Kliniskt-kemiska och hematologiska normalvärden. Svensk Vet.-T. 1965, 15, 462-476.

Pounden, W. D. \& E. Sprunger: Malignant hemangioendothelioma of a canine spleen. $\mathrm{N}$. Amer. Vet. 1947, 28, 461.

Renk, W.: Über ein phlebogenes angioplastisches Sarkom in der Mündung der V. cava cand. einer Kuh. Arch. wiss. prakt. Tierheilk. 1941, 76, 425-435.

Rubarth, S.: Några fall av primäramag- och tarmkarcinom hos husdjuren. Skand. Vet.-T. 1934, 24, 685-706.

Smith, H. A. \& T. C. Jones: Veterinary pathology. Lea \& Febiger, Philadelphia 1957.

Verma, R. D.: Haemangioendothelioma in a cow. Indian vet. J. 1963, $40,685-690$.

\section{SUMMARY}

The study comprises 49 dogs, 2 horses, and 2 cows with haemangioendothelioma, which have been subjected to autopsy over a period of 26 years. Most of the dogs were old, and there is an overrepresentation of male dogs. The results also indicate that the Alsation breed of dog is particularly susceptible to these tumours, as is the Boxer to some extent. The disease was in most cases of short duration and the most common clinical symptoms were sluggishness, fever, generalized anaemia, breathing difficulties, increased thirst, and leucocytosis. Most of the dogs fell ill and were subjected to autopsy during the period January-May. The lungs and the heart were the most frequently affected organs, but other sites were also represented, and in most cases the tumours were multiple. The right atrium, and notably the auricle, appeared to be particularly susceptible to this type of tumour, which, owing to its haematogenic spread, was mostly found in highly vascular organs. Ruptures of the tumours were common findings, together with resulting haemorrhages to the abdominal and thoracic cavities and to the pericardium. Other tumour types, mostly benign, were seen to co-exist, and among other common autopsy findings were jaundice and transudations into serous cavities.

The histological examinations indicate that the tumours can be both infiltrative and circumscribed, and that varying degrees of differentiation can be found even within the same tumour. Hyalinization and ossification of the tumour stroma occur, and the presence of haemosiderin and phagocytic cells is common.

As regard the 2 horses and the 2 cows described separately, it was found that the organs involved in these cases were the same as those that prove to be most commonly involved in the dog. In other respects, too, the findings in these cases seem to agree well with those made in dogs. 


\section{ZUSAMMENFASSUNG}

Hämangioendotheliom bei den Haustieren.

Das Untersuchungsmaterial umfasst 49 Hunde, 2 Pferde und 2 Rinder; diese Fälle von Hämangioendotheliom wurden während einer Zeitperiode von 26 Jahren obduziert. Die Hunde hatten in der Regel hohes Alter, und Hunde männlichen Geschlechts herrschten im Material vor. Ebenfalls fand sich eine deutliche Rassendisposition beim Schäfer und in gewissem Masse auch beim Boxer. Die Krankheitsdauer war in der Regel kurz. Die gewöhnlichsten klinischen Symptome waren Mattheit, Fieber, allgemeine Anämie, Atembeschwerden, gesteigerter Durst und Leukozytose. Die Mehrzahl der Hunde erkrankte und wurden obduziert in den Monaten Januari bis Mai. Meist waren Lungen und Herz angegriffen, aber auch andere Organe waren zahlreich vertreten, wobei es sich meistenteils um multiples Vorkommen handelte. Die rechte Vorkammer und speziell das rechte Herzohr bildeten den Prädilektionssitz dieses Tumors, den man übrigens infolge seiner hämatogenen Verbreitung meist in gefässreichen Organen wiederfindet. Eine Ruptur der Geschwülste war gewöhnlich mit Blutungen in die Bauch- und Brusthöhle sowie in den Herzbeutel zum Folge. Geschwülste anderer Art, meist bösartige, wurden gleichzeitig beobachtet, und von übrigen gewöhnlichen Sektionsbefunden sind Ikterus und Transsudationen in seröse Höhlen hervorzuheben.

Aus den histologischen Untersuchungen geht hervor, dass diese Tumoren sowohl infiltrative als auch begrenzende Tendenz haben können, und dass selbst innerhalb derselben Geschwulst verschiedene Differenzierungsgrade gewöhnlich vorkommen. Hyalinisierung und Verknöcherung des Geschwulststromas wurden wahrgenommen, und Hämosiderin sowie phagozytierende Zellen sind ein gewöhnlicher Befund.

Bei den beiden Pferden und Rindern, deren Untersuchungsergebnisse für sich beschrieben werden, waren dieselben Organe wie beim Hund am gewöhnlichsten angegriffen. Auch im übrigen stimmen die Resultate mit den im Hundematerial festgestellten gut überein.

\section{SAMMANFATTNING}

\section{Hämangioendoteliom hos husdjuren.}

Undersökningen omfattar 49 hundar, 2 hästar och 2 nötkreatur med hämangioendoteliom, vilka har obducerats under en period av 26 år. Hundarna har i regel varit av hög ålder, och materialet visar en överrepresentation av hanhundar. Likaledes har en tydlig rasdisposition framkommit vad beträffar schäfer, och $i$ viss mån även boxer. Sjukdomstiden har i regel varit kort, och vanligaste kliniska symtom har varit slöhet, feber, allmän anämi, andningssvårigheter, ökad törst samt leukocytos. Flertalet hundar har insjuknat och obducerats under månaderna januari-maj. Av angripna organ är lungor och hjärta de mest förekommande, men även andra organ är rikligt representerade och mestadels har det varit fråga om en multipel före- 
komst. Höger förmak och speciellt höger hjärtöra har framstått som predilektionsställe för denna tumör, vilken för övrigt genom sin hämatogena spridning mest återfinns i kärlrika organ. Ruptur av svulsterna är vanligt, med blödningar till buk- och brösthåla samt hjärtsäck som följd. Svulster av andra slag, mestadels benigna, har setts samtidigt, och av övriga vanliga sektionsfynd kan framhållas ikterus samt transsudationer till serösa kaviteter.

Av de histologiska undersökningarna framgår att tumörerna kan vara både infiltrativa och avgränsade, samt att olika differentieringsgrader är vanliga även inom samma tumör. Hyalinisering och förbening av svulststromat har setts och förekomst av hämosiderin och fagocyterande celler är vanligt.

Av de 2 hästar och 2 nötkreatur, som beskrivits var för sig, framgår, att de hos dem angripna organen har varit de som även hos hund visat sig vanligast. Även $i$ övrigt synes dessa väl överensstämma med vad som framkommit hos hundmaterialet.

(Received April 6, 1967). 